\title{
Integrity and Job Performance: The Experiences of Public Library Leaders
}

\author{
Mad Khir Johari Abdullah Sani ${ }^{1}$, Mohd Zailan Endin ${ }^{2}$, Mohamad Noorman Masrek ${ }^{3}$, \\ Noor Zaidi Sahid ${ }^{4}$, Jamiah Baba ${ }^{5}$ and Yamin Kamis ${ }^{6}$ \\ ${ }^{12346}$ Faculty of Information Management, UiTM Malaysia \\ ${ }^{5}$ Faculty of Education, UiTM Malaysia \\ Correspondence should be addressed to: Mad Khir Johari Abdullah Sani; \\ madkhirjohari@salam.uitm.edu.my
}

Received date: 10 March 2015; Accepted date: 17 December 2015; Published date: 24 May 2016

Academic Editor: Akif Lutfi Khasawneh

Copyright (C) 2016. Mad Khir Johari Abdullah Sani, Mohd Zailan Endin, Mohamad Noorman Masrek, Noor Zaidi Sahid, Jamiah Baba and Yamin Kamis. Distributed under Creative Commons CC-BY 4.0

\begin{abstract}
Librarians and information professionals, because of the complex body of knowledge, standards of entry to the profession, and the need for public confidence, frequently face ethical dilemmas. Coupled with this, the Malaysian government has asserted that public servants need to have the highest integrity in delivering services to contribute directly to the establishment of a favorable environment and to show a good relationship with stakeholders. Arguments have been made that restrictions should be written into the new code of ethics for librarians and information professionals to ensure they behave ethically when doing their jobs. Therefore, the current study seeks to explore ways to improve job performance through integrity. The study, which is a qualitative study, has used semi-structured interviews to explore the efficiency of the integrity of public library leaders with the Method Framework analysis. There are six attributes of integrity: accountability towards individuals and society; clean, efficient, trustworthy and access to information; fair, just and wise; privacy, secrecy and transparency; neutrality and professional skills and security protection found to be adopted by twenty leaders of public libraries that may affect their work performance. The findings of this study have implications for the model, policy and practice on integrity that can be adopted by libraries and other government agencies. This model can therefore be seen as a map that will guide organizations with appropriate measures when trying to improve performance through integrity. Organizations can employ the model to enhance the effects of other determinants of performance exercises to maintain leadership skills in uncertain and volatile workplaces.
\end{abstract}

Keywords: Public Librarian, Malaysia Public Library, Integrity, Job Performance, Framework Methods

Cite this Article as: Mad Khir Johari Abdullah Sani, Mohd Zailan Endin, Mohamad Noorman Masrek, Noor Zaidi Sahid, Jamiah Baba and Yamin Kamis (2016)," Integrity and Job Performance: The Experiences of Public Library Leaders ", Journal of Southeast Asian Research, Vol. 2016 (2016), Article ID 452256, DOI:10.5171/2016.452256 


\section{Introduction}

\section{Background of the Study}

There are approximately 319 public libraries throughout Malaysia employing a total of 244 professional librarians (National Library of Malaysia, 2010). The operation of MPLs is generally under the jurisdiction of the state government, however in terms of consultation, policy development, service and supports, the tasks are assigned to the National Library of Malaysia (NLM). As public libraries, their major role is to serve the information needs of the community. In addition, they are also responsible for developing and maintaining the national collections from various resources, providing facilities for their users as well as providing advice concerning library matters. These roles are in line with the national agenda to inspire a culture of knowledge in the development of the country and to foster a reading culture among Malaysians.

These roles are in line with the national agenda to inspire a culture of knowledge in the country's upholding/practicing high ethics and integrity (Hishamudin, 2010; Sidek, 2009). Additionally, public library staffs are important assets since they are social agents that advocate the development of a knowledge society in Malaysia and support the Transformation Government Programme (TGP) (Jabatan Perdana Menteri, 2010; Najib, 2009). As employees in the service organizations, they are expected to be highly dynamic and possess high integrity to perform well. It is clear that the integrity aspect is appropriate in the management of public library which emphasizes work culture that is balanced mentally, physically, spiritually, and emotionally.

These attributes can create harmony, transparency service in the workplace, and will help contribute to the development of the organization and the nation. In the present context where the government emphasizes the human model of the country in terms of intellectual knowledge, expertise and skills, integrity also plays a vital role as a component in improving the robustness of the country's performance model. Integrity is a contributor to the recognition of lives enriched by work and relationships.

\section{Statement of the Problem}

Every profession has a complex body of knowledge, standards of admission to the profession, and a need for public confidence (Vanasco, 1994). The civil service is the backbone of the government and the spearhead of national development. As one of the services that is in high demand and important, the public library is facing many challenges in upholding and enhancing its services to the masses. Public library staff, in particular, value their need for having a clear guiding philosophy as an important work value (Allen, 1998).

In particular, integrity is deemed as a vital component as it is fundamental to the functioning of private as well as public organizations. An organization with integrity reduces external regulations (Najib, 2009; Sidek, 2009); enhances cooperation with stakeholders (INTAN, 1985); strengthens stakeholders' confidence in an organization (Mahathir, 2001) and diminishes conflicts (Hubertz, Captein \& Lastuzhuein, 2007). In contrast, working without integrity, such as the occurrences of misconducts, fraud and corruption can result in enormous financial losses, severe reputational damage, bankruptcy (Sidek, 2009) and even the implosion of a country's economic and political system that leads to organizational performance problems (Hubertz, Captein \& Lastuzhuein, 2007).

In relation to public library services, there are many concepts and measures of integrity that have been defined within each of these areas, and several standards, techniques and models have been developed to capture learning, provide consistency of approach and repeatability. However, none are all embracing, or tie together/combine a cohesive view across job performance. Few are founded upon proven data and many require considerable integrity and performance models. Hence this study is to explore the 
integrity competency of librarians in Public Libraries.

\section{Significance of the Research}

This study has developed an empiricalbased framework for measuring integrity for librarians. The framework contains all the necessary and critical constructs for measuring integrity for librarians. Prior to the conduct of this study there is not yet any empirical-based framework which can be used for studying and measuring librarians' integrity. The framework should be of interest to researchers focusing on this topic. It can be used for studying integrity of public librarians in countries other than Malaysia. In addition, researchers may also be interested in validating the framework in the context of librarians working in the private sectors.

\section{Procedure definitions}

\section{Public Library}

A public library is an organization established, supported and funded by the community, either through the local, regional or national government or through some other forms of community organization. It provides access to knowledge, information and works of the imagination through a range of resources and services and is equally available to all members of the community regardless of race, nationality, age, gender, religion, language, disability, economic and employment status and educational attainment (IFLA/UNESCO, 2001; 15).

\section{Public Librarian}

A public librarian can be defined as a trained information worker in the public library service (Stevenson, 2006).

\section{Integrity}

Integrity is a concept of consistency of actions, values, methods, measures, principles, expectations and outcomes that connotes a deep commitment to do the right thing for the right reason, regardless of the circumstances (Hopkins, 2012).

\section{Literature Review}

\section{Integrity Theory and Model}

Integrity is the consistency between one's values, words and action. In Malaysia, the government is responsive in making sure that the public sector focuses on delivering services with high integrity. Ethical and integrity models are therefore reflected in all undertakings. Since the independence, the government has introduced various programmes aimed at enhancing ethics and integrity in the public service. In particular, since the 1980s, greater attention has been given to the concepts and model of 'Clean, Efficient and Trustworthy' (Bersih, Cekap dan Amanah) 'Integration of Islamic Values' (Penerapan Nilai-nilai Islam), 'Excellent Work Culture' (Budaya Kerja Cemerlang), 'Code of Work Ethics' (Kod Etika Kerja), 'Client's Charter' (Piagam Pelanggan), 'ISO 9000' and lastly, 'One Malaysia' (Satu Malaysia). Interestingly, the National Integrity Plan (NIP) is a master plan that aims to provide direction and guidance to all components or sectors of society and the country through the Model for The Enhancement of Integrity. The public library has also developed its own integrity plan for its staff which emphasizes bribe prevention in its information delivery system. Despite having initiated an integrity plan, no model or framework or research that links performance with either the individual or organizational performance has been developed. The existing initiatives are intended to enhance the integrity level of public library staff but do not incorporate performance. In the relation to library services, librarians all over the world are well aware of their profession's ethical and integrity implications. In more than 60 countries, many agencies have developed and approved a national code of ethics for civil servants which emphasizes integrity.

Although written codes of conduct and integrity are the core elements of an effective ethics and compliance program, they are not enough to simply adopt and distribute (Painne, 2005). Whether a program will have a positive impact on a job's performance, it depends on how an organization uses these tools since each

Mad Khir Johari Abdullah Sani, Mohd Zailan Endin, Mohamad Noorman Masrek, Noor Zaidi Sahid, Jamiah Baba and Yamin Kamis (2016), Journal of Southeast Asian Research, DOI: 10.5171/2016.452256 
organization is different, with unique goals, strategies and risk profiles. In addition, organizations are at different stages in the evolution of their codes of conduct and their ethics and compliance programs (Painne, 2005). To have a positive impact on the performance, an organization must tailor its code to meet its particular needs and align it with its overall business strategy as well as the goals of its ethics and compliance program. Prominent models of librarians' code of conduct are discussed below:

\section{Australian Library and Information Association (ALIA)}

The Australian Library and Information Association (ALIA) furnishes guidelines to libraries and information centres in providing services to users. ALIA is the foremost professional organisation for the Australian library and information service sector that focuses on freedom of access to public library and information services as the community has equal right to information services (Australia Library and Information Association, 2009). The association posits that interaction and relationship between library and information services and their clients should be guided by the highest standards of service quality and characterized by the highest levels of integrity. Library and information services play important roles in fostering the social, cultural and economic well-being of their communities, and therefore, the people who work in those services have responsibilities for collecting, organizing and providing access to information for the clients of their services. Even though ALIA does not directly touch on integrity but it can be seen that its policy on serving and providing information to customers has integrated elements that can be considered as integrity.

\section{Canadian Library Association (CLA)}

The Canadian Library Association (CLA) is a national, non-profit, voluntary organization, governed by an elected Council and Board of Directors. The Association includes five constituents that represent the interests of academic libraries, public libraries, school libraries, special libraries, and library trustees. CLA is the national voice for Canada library communities (Canadian Library Association, 2012). Similar to ALIA, CLA does not explicitly touch on librarian conduct or elements of integrity but has developed seven values which include elements of integrity investigated in the study. The seven values are used as a model employed by the library association. These values are intellectual freedom, diversity, transparency and open communication, accountability, universal access to library service, member voices and contributions and collaboration.

\section{IFLA Code of Ethics}

The IFLA Code of Ethics for Librarians and other Information Workers is a code related to library and librarians worldwide. It is clear that the IFLA Code of Ethics is related to the study as it is about librarianship and how they should treat their customers and provide services. This Code of Ethics and Professional Conduct is offered as a series of ethical propositions for the guidance of individual librarians as well as other information workers, and for the consideration of Library and Information Associations when creating or revising their own codes. The Code aims to encourage reflection on principles on which librarians and other information workers can form policies and handle dilemmas, improve professional selfawareness and provide transparency to users and society in general.

The attributes of IFLA Code of Ethics and Professional Conduct include the following:

- access to information

- responsibilities towards individuals and society

- privacy, secrecy and transparency

- open access and intellectual property

- neutrality, personal integrity and professional skills

- colleague and employer/employee relationship 


\section{Library Association of Malaysia}

The Library Association of Malaysia is one of the associations that bring together all libraries in Malaysia. Under Librarians Association of Malaysia the code of ethics for librarians was established to help set standards of professional conduct expected of members in line with the aims and objectives of the Association. It also helps regulate professional behavior in terms of safeguarding the interests of the community served. As librarians significantly influence or control the selection, organization, preservation and dissemination of information, they are entrusted with the responsibility to provide their clientele access to information. Hence a code of ethics is vital in defining their professional responsibility. Librarians must uphold and maintain the principles as laid down in the Constitution of the Librarians Association of Malaysia (Library Association of Malaysia, n.d.). In addition to this, the Code of Ethics is one of the National Integrity Plan (NIP) models which outlines the roles and functions of integrity.

\section{Roles and Functions of Integrity}

In the context of the individuals, integrity plays important roles that reflect the ability of the individual in performing assigned tasks. Nikitina (n.d.) argued that integrity is the core quality of a successful person. Integrity acts as the foundation of character that describes an individual as an honest person in every area of his or her life. Meanwhile, Hidalgo (2002) stated that integrity acts as a guideline, a benchmark, a point of reference or a goal that is used to make decisions that rely on truth and honesty. A study by Eisenhower (2013) clarified the functions of integrity as a positive attribute that is fundamental for leadership. Therefore, it is imperative that leaders, lead with integrity, honesty and values; should be concerned with individual wholeness and conscience, have the quality of being true to oneself; and recognize that it is essential to maintain personal and professional relationships.

\section{Description of Methodology}

This study employed a qualitative approach. Qualitative research is more indepth and holistic than quantitative, generating rich material on which to base the findings of a piece of research (Polit \& Beck, 2010). The study explored how the integrity competency of librarians affects their performance via face-to-face interviews. Interview was used to obtain views, attitudes and perceptions, which are termed as "personal constructs" (Shek, 2012). This qualitative style of inquiry intends to gain an "authentic understanding of people's experiences and perceptions" (Shek, 2012). Salmon and Rickaby (2012) suggested that qualitative study "seeks deeper truth" and sets out to understand or interpret phenomena by the meanings that people give to them. Qualitative research methodologies, unlike quantitative methods are best able to take account of the nature of human perceptions, thoughts and ideas, which recognize the complex and dynamic quality of the interpersonal world (Salmon \& Rickaby, 2012). Given the ethics, integrity, perceptual, interpersonal and relational nature of job performance, a qualitative approach to this study is highly appropriate in order to yield relevant insights (Proctor-Thomas, 2002).

Interviews were conducted with 8 senior librarians and 12 librarians. The data then were analyzed and transcribed using the Framework Method and emerging themes from the constructs were elicited, and compared to the literature of integrity and performance. The Framework Method sits within a broad family of analysis methods often termed as thematic analysis or qualitative content analysis. This approach identifies commonalities and differences in qualitative data, before focusing on relationships between different parts of the data, thereby seeking to draw descriptive and/or explanatory conclusions clustered around the themes. The Framework Method was developed by Ritchie and Spencer (2003), from the Qualitative Research Unit at the National Centre for Social Research in the United Kingdom in the late 1980s for use in large-scale policy

Mad Khir Johari Abdullah Sani, Mohd Zailan Endin, Mohamad Noorman Masrek, Noor Zaidi Sahid, Jamiah Baba and Yamin Kamis (2016), Journal of Southeast Asian Research, DOI: 10.5171/2016.452256 
research. The Framework Method provides clear steps and produces highly structured outputs of summarized data. It is therefore useful where multiple researchers are working on a project, particularly in multidisciplinary research teams where not all members have experience of qualitative data analysis, and for managing large data sets where obtaining a holistic, descriptive overview of the entire data set is desirable.

There are eleven questions in the interview, which were developed based on the Malaysian National Integrity Plan (NIP); Code of Ethics, American Library Association (ALA), (2008); Australian Library and Information Association (ALIA), (2001); International Federation of Library Associations and Institutions (IFLA/UNESCO) (2001) and National Library of Malaysia (NLM) (2004) and comprise of six main areas. They are accountability towards individuals and society; clean, efficient, trustworthy and access to information; fair, just and wise; privacy, secrecy and transparency; neutrality and professional skills and security protection

\section{Findings}

The twenty librarians who participated in the interviews provided numerous dimensions into what integrity for librarians looks like in their day-to-day practice. Their narrative responses were coded and categorized according to the six attributes of ethics and integrity: accountability towards individuals and society; clean, efficient, trustworthy and access to information; fairness, just and wisdom; privacy, secrecy and transparency; neutrality and professional skills and security protection. This section will detail examples of their narrative responses that demonstrate the manifestation of integrity in the public library practice. Overall, there were 102 integrity practices and experiences reported by the public librarians and were divided into six distinct domains of integrity as identified by the Code of Ethics of Librarians and National Integrity Plan (NIP) which are: responsible (accountability towards individuals and society); clean, efficient, trustworthy and access to information; fairness, just and wisdom; privacy, secrecy and transparency; neutrality and professional skills and security protection.

\section{Accountability towards Individuals and Society}

Accountability refers to the responsibility of employees to complete assigned tasks, to perform the duties required by their job and to be present for their proper shifts in order to fulfill or further the goals of the organization and society. If an employee's tasks are not completed and functions of the job are not performed effectively, then that employee will also be responsible for dealing with the impact. One of the attributes to measure integrity is accountability of the employee. Each employee should have accountability in his/her-self or in the workplace. Indirectly, this element will reflect the employee's job performance. To illustrate, R1 faced a situation that involves accountability when working as a librarian. R1 emphasized that:

I never do and never take credit on the works of others. But, other people have taken credit from the work that has been done by me. I'll try my best to mention other people's names for the work that we are doing together. In this case, the top management needs to play their roles, be strict and look at this situation, not just hear about it. With that, the employees will follow the directions.

R4, 5 and 12 also added another example:

The employees should have [responsibility] and [when they] feel responsible about their work they will be a timely person such as coming early to the workplace.

From the situation above, R9 displays high accountability. $\mathrm{He}$ is committed and accepts his responsibilities while thinking of the users (customers). Similarly, R13 also shared his opinions about this attribute that affects job performance. R13 expressed that:

Personally, accountability is required in each individual no matter in the workplace or anywhere else. As an example, the problem in the workplace always happens to 
individuals because they no have accountability. Sometimes, many employees get a name from the work of others. This situation has certainly been a culture in each job. In addition, if the work has been done together with other staff; I will state that this work is not only completed by me. If one does not have accountability, indirectly this situation will happen in the workplace. In the workplace, the employees should have the attitude of lending mutual help to each other and also not selfish.

This indicates that accountability is an important element as it does not only affect individual job performance but also the relationship with other staff. Without accountability it will lead to a situation such as the above which is taking credit on the job of others.

Accountability is indeed associated with job performance. R2 and R7 noted that:

Seriously I can say that the people that take credit of other works really happened in the workplace. It happened because of selfinterest to get a name although is not their own work. I also faced the people that always flatter in workplace. What I can see, there are two situation that the employee be like this are common good and for own selfinterest. In addition, I think accountability not just like this situation but also such as the employee complete their works in period given and do the works sincerely.

In terms of receiving credit for work that was mostly completed by others, as R8 experienced, this situation commonly happened in their line of work. On these points, a key respondent, K elaborated that:

A few years earlier, I was always faced with this situation and also did such a thing. For example, when attending any program I never brought up the name of my organization. But, after having gaining more experience, I think this work is my accountability not only for myself but also for my organization. I can overcome this situation by sharing any work that has been done together and not be selfish. It is clear that accountability plays an important role. Without it, it will lead to unfairness in the work environment. The interviewees show high accountability in their work as they realize the impact of having this value in their personal life and work.

\section{Clean, Efficient, Trustworthy and Access to Information}

Since the 1980s, in particular, greater attention has been given to the concept of "Clean, Efficient and Trustworthy" (Bersih, Cekap dan Amanah) to prevent corruption. In the context of library services, the concept refers to employees practicing spiritual and physical cleanliness, performing their duties efficiently, quickly and accurately, putting trust in their duties not deviating, abusing power or breaching trust, are not corrupt and most importantly, not openly accessing information. The findings of the study show that different individuals have their own interpretation of the clean, efficient and trustworthy elements of integrity. They do practice these elements in their work in various areas such as services. Interviewees R6 and R11 hinted that they did practice this attribute in their work:

I'm holding to IQRA. I put my faith in Allah and Quran and Alhamdulillah in everything that I was entrusted, I try my best to be honest and truthful. I was responsible for developing as many special collections so I have to make it available and provide the best possible services to users. I need to think, make a wise decision and consider its merit. The budget I get to develop the collection and can be accessed by all users, I need to use it wisely, if not, it will lead to a waste of resources if it is not being used.

R14, R20 also added another example:

If I used the budget for another thing outside of the purpose of the special collection development it means I have breached the trust. It shows that I do not have integrity and it will affect the library.

R3, R7, R5, R15 provided a similar example of the clean, efficient and trustworthy elements by associating them in their line of work:

I have to deal with vendors to purchase new materials for libraries and sometimes I meet

Mad Khir Johari Abdullah Sani, Mohd Zailan Endin, Mohamad Noorman Masrek, Noor Zaidi Sahid, Jamiah Baba and Yamin Kamis (2016), Journal of Southeast Asian Research, DOI: 10.5171/2016.452256 
with vendors who want to give bribes in order to get the contract and sometimes a third party tried to intervene. We cannot avoid such incidents but what is more important is we must strengthen ourselves to fight corruption or being biased. We must be honest in our work.

This finding shows that the respondents have high integrity in fulfilling their work responsibilities. It also shows that integrity does affect one's job performance and the organization.

R17 also added:

Integrity is very important in oneself, not only as an employee but as a human. I need to achieve my target for my work every year, so I try to do my best to reach that target.

R12's opinion is quite similar to R17 because in providing services to users it is important to deliver the feeling of sincerity, trustworthiness and honesty to users:

All employees must perform their duties honestly and must be thinking about the benefits for all. Each materials purchased in the library must take into consideration the positive and negative effect. We do not want to purchase it blindly and then user does not use the materials. It will waste the funds provided by the library. In other words, when employees are not honest in the work entrusted to them, this indirectly affects the integrity of the organization.

For R10, lack of honesty and trust in performing their duties has serious implications:

Without trust and honesty, it will indirectly affect the good name of the organization as well as give bad impression to users about the library and also the staff. As a librarian we should strive to provide the best possible services to our users.

Even though clean, efficient and trustworthy have become the elements of integrity, and can actually be found in many organizational policies, rules and regulations, if they are not practiced, it will affect job performance as they are directly connected to the spiritual aspects. R13 explained that:

In whatever work or job we do, intention \{niat\} is important. If our intentions are honest, sincere InsyaAllah everything we make will work and bring good returns. If faith in them is already diverted from the very beginning the quality of work will suffer and does not get the blessing [of God].

R15 also indicated that:

However if we are not honest in doing our work it will result in users not getting the materials they want and more importantly, it will impact on the individual's own spiritual being.

As discussed above, being clean, efficient and trustworthy is one of the important elements of integrity that must be practiced by each employee as it will not only affect the performance of the employee but also the organization.

\section{Fair, Just and Wise}

In the process of exploring the integrity competency of librarians, fairness, just and wisdom were considered as attributes of integrity that every employee should have. Being fair can be defined as treating people equally without favoritism or discrimination while just it is an attitude of behaving according to what is morally right and fair. Being wise, on the other hand, is an individual having or showing experience, knowledge and good judgment. A librarian needs to be fair, just and wise to his/her colleagues and in providing services and access to information to users. R18 exemplified:

I have been in a situation where librarians have been providing misleading information to the users and it resulted in user dissatisfaction. I cannot immediately blame the librarian or users, it is wrong to judge without questioning. I have to be fair to both and make a wise decision. So, I talk to both to know what actually happening."

In carrying out tasks as librarians, librarians have to be rational in handling delicate situations. Although the library is

Mad Khir Johari Abdullah Sani, Mohd Zailan Endin, Mohamad Noorman Masrek, Noor Zaidi Sahid, Jamiah Baba and Yamin Kamis (2016), Journal of Southeast Asian Research, DOI: 10.5171/2016.452256 
an organization that has its own rules and regulations, there are situations that require bending of the rules for the benefit of the users. R8 explained:

Rules are made to ensure the effectiveness and efficiency of work done as well and in providing service to users. However, there is time that we need to consider or bend the rules. For example, the library forbids users to drink and eat inside in the library because they want to ensure the safety of the materials but the library exists to serve the users so users' opinion need to be taken into account. Now the library allows user to drink inside the library and provides a cafeteria outside the library. Yes, we do bend the rules for the benefits of both.

Public libraries provide service to the public which includes a wide range of users from children to adults. It may include users from different education backgrounds. It is a librarian's job to meet the users' information need fairly as R1 expressed:

We provide service to users without looking at his/her background. All users get the same treatment regardless of age, race, religion, class.

Being fair, just and wise can influence a librarian's ability to be considerate and tolerant, as expressed by R15:

We are just human, we do make mistake. For example, I have experienced someone stretching the rules of library work such as they do not come on time, do not meet work quota. However as a leader or the top management we cannot blame the workers, point fingers or make hasty decisions. First, we must observe, monitor, give advice, and give training and so on. After all that and they still remain unchanged then we will give them a warning letter however that will be the last resort. We try to find the best solution and we do not fire employees or make decisions blindly. We try to be prudent, thoughtful, and careful and wise, practice a two- way communication and empathy in finding the best solution and making decision.

\section{Privacy, Secrecy and Transparency}

Transparency is openness of decisions and actions. Put in another way, it means a free flow of information about decisions and actions, from the source to the recipient. Transparency is a necessary part of accountability but it is not the same as accountability. It is also an attribute of integrity that will affect the job performance of an individual. R14 stated that:

I agree that an individual should have transparency in the workplace. I say this because any decisions we make need to be transparent. As a librarian (S41), I have no rights in big decisions involving matters of management. I only just need follow the directions from the top management. For librarians like me, I only can make decisions that relate to my job tasks. In addition, sometimes I have to agree although I am not satisfied and feel uncomfortable with the decision made by the top management because of many aspects. For example, I had suggested that the building must be consolidated but the top management did not agree with me because of cost. Because of that I always heard complaints from the users because they find it difficult to access the information. The users have right to complain about the library. We should provide the services in order to fulfill their demand.

This shows that it is important to have transparency in an organization because everyone's job tasks are related to one another. Furthermore, transparency also means giving the right explanation, answer or decisions. R10 mentioned that:

For me, in doing work, it is impossible that the employee does not commit any mistake. As an example, I have made a decision that violates my organization's policy. I do this mistake not for my self-interest but it is for my organization in implementing the project. I will look at the situation if it does not affect my organization, I just proceed to facilitate and give my best to the organization.

This indicates that, even though it is important to follow the decision of the top

Mad Khir Johari Abdullah Sani, Mohd Zailan Endin, Mohamad Noorman Masrek, Noor Zaidi Sahid, Jamiah Baba and Yamin Kamis (2016), Journal of Southeast Asian Research, DOI: 10.5171/2016.452256 
management, there will always be instances that librarians need to do what is right. This is because as individuals who directly face the users and carry out the task, it is important to know what is best for that particular situation. R17 distinctly stressed that:

In any decision, we must have discretion in many aspects. The most important is when make a decision we need make sure this decision will not affect our own integrity and not to break the rules of library. As I experienced, my subordinate always have personal problems that affect their job performance. In this case, I need know the real problems in order to prevent fraud that can break the rules and indirectly avoid matters that affect my integrity. The most important is transparency in making decisions and giving answers and being honest in our explanations.

She added:

As an example, a staff needs to be back at home 1 hour early. I make a decision based on whether her problem is probable for me, I will give permission for her to leave early but she needs to replace it [the hour]. As humans, we cannot run away from problems. She has the right as a human. The discretion and respect to each other must be in oneself.

Every action requires careful thought as it impacts everyone and the organization. R9 was very open in describing the issue, as exemplified in the following:

Many things need to be considered in making a decision, especially involving big decisions in the management. Any actions cannot be made in a rush because we only get the negative impact to ourselves and organization. One discussion should be done in making any decisions.

Moreover, R4 pointed out that:

I have experienced making one decision to sack a staff because of many aspects. In this situation, we should follow the guidelines and cannot freely make a decision without any discussion with the management. We also need to consider and look what he has been done before, his behaviour and reaction, try to give advice, opportunities and space to him in solving the problems. Through this, we can find the solution and change his behaviour. The findings show that transparency is one of the important elements that should exist in every individual.

\section{Neutrality and Professional Skills}

Professional and competent is one of the attributes of integrity. Professional refers to an individual having the required skills, good judgment and polite behaviour. Put in another way, professional is the habitual and judicious use of communication, knowledge, technical skills, clinical reasoning, emotions, values, and reflection in the workplace. Competence, however, is more expansive and all-encompassing as it represents the totality of knowledge, skills, attributes, behaviours and attitudes as well as, the ability to regulate these competencies into the full range of activities necessary for professional practice.

An individual that is reliable and has a high level of professionalism, and the best interests of the organization, profession, religion, race and nation is needed in the organization. In explaining the relationship between professionalism and competence with job performance, R3 expressed that:

Emphatically, an employee needs to be a professional and competent person in the workplace because it is one of the elements of integrity. For example, a librarian misplaced materials on the shelves. The users have complained to Public Complaints Bureau (Biro Pengaduan Awam) about this problem. The users have their own right in accessing information. The librarian needs to know the users' requirement in the library. For me, as librarians, we need be professional and open minded because it is our role to provide services to the users. We need to handle it as best as possible because it is our duty. The users will look at our ability in resolving the problems. 
This is supported by R13 that clearly described:

Seriously, if we do not have this in our work it automatically will affect the development of the library and our job performance is also affected. As example, we purchase the materials that the users do not use and are not related to their interest. Indirectly, we will be blamed by users and the top management. The top management trusts us to provide the best services to users. From that, we cannot make them lose faith in our ability. We need to make sure we can do the work effectively and convince them of our ability.

This means, in overcoming problems especially in making decisions, the employee should be professional and competent. R12 expounded:

I also deal with problems that required me to be professional and competent. As an example, the library staff that had a misunderstanding with the user that came to the library. This problem happened because she was under pressure and made a mistake in talking with the user. I handled this problem by investigating the exact cause of this misunderstanding. I cannot blame anyone in this situation. I talked to them separately to know their problem. Finally, this problem was resolved and both of them apologized to each other. I am always faced with this kind of problem but it is my responsibility. I believe if we adhere to religion, every problem can be resolved. The employee cannot give up, Insha'Allah [she/he] will be professional to prevent the problem. In the workplace, the employee needs to have tolerance, forgive each other, be prudent and not be rude.

The external influence can affect an employee's integrity. R14 expressed that:

In the context of library, I never feel uncomfortable with my job but the ills of users are common for me as a librarian. I must follow the rules set in the library and also have discretion. If one does not possess this, it will be uncomfortable in doing job tasks. In addition, while dealing with vendors, sometimes we have pressure from third parties that recommend and compare their items with other vendors. It makes me feel uncomfortable. But, with the experience that I have, I handle it professionally in making decisions for the organization. I know all of these are only the vendor's strategies in attracting us to purchase their materials.

R10 added:

For example, in purchasing the system with the price of 5 million, it involve large of amounts. The problem here is arise one against each other and we blamed when in fact it is due to other. Without integrity in oneself, it also can lead to corruption although we already carry out our responsibility. The findings indicate that the interviewees are aware of their responsibilities and agreed that a staff should be professional in his/her work for the benefits of organization.

\section{Safety Protection}

Safety protection is one of the integrity attributes that is employed by public librarians. Safety protection in this context is understanding and complying with the regulations and safety instructions; understanding and complying with the health of employees and customers; and lastly, creating and promoting a working environment in accordance with staff physiology and psychology. This element is normally established as part of the library policies, rules and regulations that requires staff and users to follow and was developed to ensure the safety of all that is usually underestimated and ignored by staff. R3 and R7 expressed their similar opinion and experiences on this:

I do realize that improvement should be done not only for the comfort of library staff but also users. It will encourage and raise employee morale to work and give the best service to library users. But now we need an environment and decoration that able to attract people to visit the library. Furthermore, we need to provide more services that meet the users demand nowadays. 
This motion was seconded by R12 and R20, when they added that they did not feel comfortable with the library building being separated because:

it is not only making it difficult for the staff but also not convenient for the users. Users need to go to a different building to search for reference and borrow library materials. Indirectly it affects the process of providing service and access of materials to users.

However, it was different for R10:

During my service as a librarian, even though I might face certain obstacle I do not feel uncomfortable. I did follow and obey all the rules and feel comfortable with my work environment.

Based on the findings, this constituent seems to exist in the organization but it is not widely emphasized.

\section{Conclusion and Recommendation}

Evidence collected through interviews indicates that appropriate attributes of the integrity model by the Code of Ethics of Librarians and National Integrity Plan (NIP) are undeniably important and germane amongst Malaysian public librarians. These dimensions are accountability towards individuals and society; clean, efficient, trustworthy and access to information; fairness, just and wisdom; privacy, secrecy and transparency; neutrality and professional skills and security protection. Given that the dimensions of integrity in the Code of Ethics of Librarians and National Integrity Plan (NIP) model have been empirically validated in diverse professions in various organizational settings, this study further strengthened the model in the context of Malaysian public librarians. Unlike previous studies that mainly adopted the survey method, this study adopted interviews as the main data collection method. Based on the findings of the study, a follow-up study is probable to be carried out using the survey method so as to further ascertain the dimensions of the model. From the practical viewpoint, the study has further strengthened the model developed by the Code of Ethics of
Librarians and National Integrity Plan (NIP). The practical implication is that the management of the Malaysian public libraries should consider effective enrichment programs that promote and enhance integrity suitable for the public library staff that can later be emulated by the other government sectors. Public library staffs who have a high level of integrity are less likely to leave an organization and reduce bribery, corruption, and employee misconduct. Additionally, librarians are more likely to engage in activities that further enhance their knowledge and performance. The findings of the study may have implications for integrity policies and training. A multifaceted strategy is deemed to be most effective in public service to improve the integrity of service organizations. The conduct of this study is not without limitation. The number of respondents involved in the study was only twenty. Hence, future studies focusing on the same subject should consider using the survey method with questionnaires as the data collection tool so as to ensure that more respondents can participate in the study.

\section{Acknowledgment}

The researchers would like to extend their gratitude to Higher Education Ministry of Malaysia for sponsoring the project under the Research Acculturation Grant Scheme (RAGS) (600-RMI/RAGS 5/3 and Universiti Teknologi MARA.

\section{References}

1. Mad Khir Johari Abdullah Sani, Mohamad Noorman Masrek and Adnan Jamaludin. The Need To Explore Emotional Intelligence (EI) Skills Amongst Malaysian Public Librarians (MPLs). Proceeding of the 18th International Business Information Management (IBIMA) Conference, 9-10th May 2012, Istanbul Turkey (ISBN: 978-098214897-6).

2. Mad Khir Johari Abdullah Sani, Mohamad Noorman Masrek (2013). The relationship between emotional intelligence and occupational performance among Malaysian public librarians. Unpublished 
PhD Dissertation, Universiti Teknologi MARA, Selangor.

3. Allen, G. (1998). Work values in librarianship. Library \& Information Science Research 20(4), 415-424.

4. American Library Association (2015). Code of ethics of the American Library Association. Retrieved from http://www.ala.org/advocacy/proethics/c odeofethics/codeethics

5. Arlington (2010). Corporate executive board uncovers key drivers of cultural integrity and its role in risk: Outlines corrective actions to increase corporate performance and shareholder return. Retrieved from http://ir.executiveboard.com/phoenix.zht $\mathrm{ml}$ ? $=113226 \& \mathrm{p}=$ irolnewsArticle \&ID=1471372\&highlight=

6. Autralian Library and Informtaion Association (2015). Policies, standards and guidelines. Retrieved from https://www.alia.org.au/aboutalia/policies-standards-and-guidelines

7. Bell, R. C. (2003). The repertory grid technique. In F. Fransella (Ed.), Personal Construct Psychology (pp.). Chichester: John Wiley and Sons Ltd.

8. Beyond Acess (2012). Libraries Powering Development. Retrieved from: http://www.beyondaccesscampaign.org/w p-content/uploads/2012/03/BeyondAccess-Libraries-MDGs-Small.pdf The public library service : IFLA/UNESCO guidelines for development

9. Blundell, J., Wittkowski, A., Wieck, A., \& Hare, D. J. (2012), Using the repertory grid technique to examine nursing staff's construal of mothers with mental health problems. Clinical Psychology \& Psychotherapy, 19, 260-269.

10.doi: $10.1002 /$ cpp.747

11. Borman, W. C., \& Motowidlo, S. J. (1993). Expanding the criterion domain to include elements of contextual performance. In N. Schmitt \& W.C. Borman and Associates (Eds.)
12. Campbell, J. P., McCloy, R. A., Oppler, S. H., \& Sager, C. E. (1993). A theory of performance. In E. Schmitt, W. C. Borman, \& Associates (Eds.), Personnel selection in organizations (pp. 35-70). San Francisco: Jossey-Bass Canadian Library Association (2015). About CLA. Retrieved from http://www.cla.ca/AM/Template.cfm?Sect ion=About_CLA

13. Craig, S. B., \& Gustafson, S. B. (1998). Perceived leader integrity scale: An instrument for assessing employee perceptions of leader integrity. Leadership Quarterly, 9(2), 127-145.

14. Collins, D. (2011). Designing ethical organizations for spiritual growth and superior performance: An organization systems approach. Journal of Management, Spirituality \& Religion, 7(2), 95-117.

15. Davis, J. H., Schoorman, F. D., Mayer, R. C., \& Hwee, H. T. (2000). The trusted general manager and business unit performance: Empirical evidence of a competitive advantage. Strategic Management Journal, 21(5), 563-576.

16. Downing K. E. (2009). The relationship between social identity and role performance among academic librarians. Unpublished PhD Dissertation. The University Of Michigan, United States.

17. Eisenhower, D. D. (2015). The Eisenhower approach to leadership. In. encyclopedia.com. Retrieved from ttp://www.encyclopedia.com/topic/Dwigh t_David_Eisenhower.aspx

18. Hernon, P., \& Whitman, J. R. (2009). Delivering satisfaction and service quality: A customer based approach for libraries. New Delhi: ALA Indiana.

19.Hidalgo, C. Z. (2002). Integrity. Retrieved from

http://www.webweevers.com/integrity.ht $\mathrm{m}$

20. International Federation of Library Associations (2015). IFLA Code of Ethics for Librarians and other Information Workers. Retrieved from 
http://www.ifla.org/news/ifla-code-ofethics-for-librarians-and-otherinformation-workers-full- version

21. Malaysia. Jabatan Perdana Menteri (2010). Program transformasi kerajaan: Pelan hala tuju - ringkasan eksekutif.

Putrajaya: Unit Pengurusan Prestasi dan Pelaksanaan (PEMANDU).

22. Malaysia. National Institute of Public Administration. (1985). General trends in civil servicer eforms in Malaysia, In Bangkok. Government of Thailand, Office of the Civil Service Commission (Ed.), Trends in civil service reforms in ASEAN countries, (pp. 181-197). Bangkok: Office of the Civil Service Commission.

23. Malaysian. Prime Minister Office (2015). National Intergrity Plan. Retrieved from

http://www.pmo.gov.my/dokumenattache d/Dasar/NIP.pdf

24. Mohd Najib, A. R, (2009). 1 Malaysia concept can earn the country respect. Retrieved from

http://www.1malaysia.com.my/index.php? option $=$ com_content $\&$ view $=$ article $\& i d=251$ 8\&Itemid=56\&lang=en

25. Motowidlo, S. J., \& Van Scotter, J. R. (1994). Evidence that task performance should be distinguished from contextual performance. Journal of Applied Psychology, $79,475-480$.

26. Nikitina, S. (2002). From a community of people to a community of disciplines: The art of integrative humanities at St. Paul's School. Retrieved from

http://thegoodproject.org/wpcontent/upl oads/2012/09/GoodWork17.pdf

27. Paine, L. (2005). Does your company"s conduct meet world-class standards? Harvard Business Review, Perpustakaan Negara Malaysia (2015). Laporan tahunan. Retrieved from

http://www.pnm.gov.my/index.php/pages /view/306

28. Persatuan Pustakawan Malaysia. (2015). Code of ethics. Retrieved from http://www.ppm55.org/code-of-ethics/

29. Piccolo, R. F., Greenbaum, R., Den Hartog, D. N., \& Folger, R. (2010). The relationship between ethical leadership and core job characteristics. Journal of Organizational Behavior, 31, 259-278.

30.Polit, D. F., \& Beck, C. T. (2010). Generalization in quantitative and qualitative research: Myths and strategies. International Journal of Nursing Studies, 47(11), 1451-1458.

31. Quinn, B. A. (2005). Enhancing academic library performance through positive psychology. United Kingdom: Haworth Press.

32. Resick, C. J., Hanges, P. J., Dickson, M. W., \& Mitchelson, J. K. (2011) A Crosscultural examination of the endorsement of ethical leadership. Journal of Business Ethics, 63(4), 345-359.

33. Ritchie J., \& Lewis, J. (2003). Qualitative research practice: A guide for social science students and researchers. London: Sage.

34. Salmon, D., \& Rickaby, C. (2012). City of one: A qualitative study examining the participation of young people in care in a theatre and music initiative. Children \& Society. doi: 10.1111/j.10990860.2012.00444.x

35. Seale, C., \& Silverman, D. (1997). Ensuring rigour in qualitative research. European Journal of Public Health, 7, 37984.

36. Shamsudin Osman (2005, July). Psikologi menjana kecemerlangan. Paper presented at Majlis Perasmian Seminar Psikologi Dalam Perkhidmatan Awam. Pusat Konvensyen Antarabangsa Putrajaya.

37. Shek, D. T. L. (2012). Evaluation of a positive youth development program based on the repertory grid test. The Scientific World Journal, 2012, 1-12, doi:10.1100/2012/372752

38. Sidek, H. (2009, August). Public services: People first, performance now. Paper

Mad Khir Johari Abdullah Sani, Mohd Zailan Endin, Mohamad Noorman Masrek, Noor Zaidi Sahid, Jamiah Baba and Yamin Kamis (2016), Journal of Southeast Asian Research, DOI: 10.5171/2016.452256 
presented at Public Service Commission Malaysia. Le Meridien Kota Kinabalu, Sabah.

39. Sinha El-Saaba (2001). The skills and career path of an effective project manager. International Journal of Project Management, 19, 1-7.

40. Vanasco, R. R. (1994). The IIA code of ethics: An international perspective. Managerial Auditing Journal 9(1), 12-22.

41. Viswesvaran C, Ones D. S., \& Hough L. M. (2001). Do impression management scales in personality inventories predict managerial job performance ratings? International Journal of Selection and Assessment, 9, 277-289.

42. Wedgeworth, R. (1993). World encyclopedia of library and information services. ( $3^{\text {rd }}$. ed.). Chicago : American Library Association.

43. Wesley, S., Basran, S., Hayward A., \& Harris D. (2011). Corporate ethics policies and programmes: UK and continental europe survey 2010. United Kingdom: Institute of Business Ethics. Retrieved from http//www.ibe.org.uk 